\title{
DISCUSSION
}

\section{CAN POETRY BE OF VALUE IN THE WORLD OF BUSINESS?}

Whilst most people can see a potential connection between poetry and advertising, they become sceptical when faced with the notion that reading poems and experiencing the process of getting to grips with their possible meaning can help in business. The suggestion that poetry can help with strategic thinking, with creativity and innovation, in decision-making, in communications, in the way we look at situations, the way we think, the way we interact with others or the way we express our opinions leaves many people struggling. And yet - reputable companies, world-class CEOs, institutions and scholars propound the value of poetry for business. This discussion paper, based on a review of the available literature, is a top level exploration of how poetry might be of value in the world of business.

Concerned that business and management strategy were too often reduced to a narrow, toolbox approach, the Strategy Institute of the Boston Consulting Group commissioned Clare Morgan to work with them on a project exploring the relationship between poetry and strategic thinking. The investigation of the role poetry might play in business by Morgan and her colleagues is recorded in the book, What Poetry Brings to Business (Morgan, 2010). Ted Buswick, who initiated the project, said: "What our theories offer isn't an 'alternative' approach. It's a tough, skills-based initiative aimed at adding to the repertoire of analysis-based thinking spaces" (Buswick, Morgan, and Lange, 2005).

In 2007 Sidney Harman, founder of Harman Industries said: "I used to tell my senior staff to get me poets as managers," for him: "Poets are our original systems thinkers. They look at our most complex environments and they reduce the complexity to something they begin to understand" (Rubin, 2007). When asked about his success in turning Jell-O from a business with a seven million dollar loss to a twenty million dollar success Dana Goia, a poet and author of Can Poetry Matter? replied: "I looked at things differently. I made associative connections. I thought around and beyond and through the data that confronted me" (Morgan, 2010). He ascribed this to the fact that he was also a poet.

Business schools use poetry to teach business studies; for example, Babson College requires its MBA candidates to take a five-week creativity workshop early on in the program. Students are randomly assigned to one of seven art seminars which include poetry. Professor Mary Pinard says: „There is a lot of ambiguity in the creative process, and that's hard for people who want answers. [...] Yet successful entrepreneurs are people who can stay open to possibilities, take risks, and find new solutions to problems. [...] The nature of what entrepreneurs do is very close to what poets do."

Lieutenant General James Lennox, Superintendent of the United States Military Academy at West Point from 2001 to 2006, believed that poetry was of value in achieving good communications: "Those who can't communicate can't lead. Poetry, because it describes reality with force and concision, provides an essential tool for effective communication. [...] In studying poetry, cadets gain a unique appreciation for the power of language" (Lennox, 2005). The 2016 curriculum not only includes poetry in courses on British Literature, American Literature and World Literature but a 36-hour course on poetry. As well as developing communication skills Lennox also considered that "poetry confronts cadets with new ideas that challenge their worldview. [...] In teaching cadets poetry, we teach them not what to think, but how to think" (Lennox, 2005). "We may not produce a poet laureate at the United States Military Academy. If, however, we develop graduates who can communicate clearly, think critically, and appreciate the world through different perspectives, we will provide the Army and the nation with better leaders" (Lennox, 2005).

Clare Morgan suggests that poetry can help in business in the following ways (Morgan, 2010): 
- A poem is multidimensional which develops our ability to detect different modes of meaning and to deal with ambiguity and uncertainty.

- A poem doesn't offer closure - this teaches us to handle non-resolution.

- A poem isn't based in a logical deductive mode and so we learn to make associative connections.

- Poems can show the ordinary as extraordinary which encourages us to question givens and makes us more aware of complexity.

- A poem is almost infinitely interpretable and can help us to consider the views of others, to recognise that 'meaning' is unstable and to examine and revise our current insights and perceptions.

- A poem operates at different levels of accessibility which could enable us to detect weak as well as strong signals and to seek less obvious linkages.

- A poem is full of coexistent complements and contradictions which could develop our ability to time judgements carefully and be aware that binary thinking is not enough.

- By drawing attention to human needs and motivations poetry could help us to make decisions in a more comprehensive context and address ethical issues.

- By exploring emotional complexity poems could help us develop the ability to offer wholeness of response.

Let's briefly look at the possible role of poetry in some specific business contexts.

\section{Poetry and Marketing}

Poetry and advertising are no strangers. Klepper and Piller (2000) contend that "Socially, advertising has long taken over the community-building function of the bard, gluing together individuals with the semiotics of shared symbols and narratives". Referring to the advertising slogans: "Have a Break, Have a Kitkat" and "Wonderbra for the way you are", Clare Morgan suggests: "The power of poetry has been added to the words of the advertisements to reach beyond those words and elicit a response that does not depend on logic or fact. The poetry aspect has reached into the customer's decisionmaking process to assess nonlogical but highly decisive responses that affect the purchasing patterns of whole sectors of society" (Morgan, 2010).

Poems have often been used to market products and this was especially evident at the start of the new millennium. In March 2000, the New York Times ran an article on the use of poetry by marketing departments reporting that "American Airlines is the latest company to jump on the poetry bandwagon. In April, National Poetry Month, flight attendants on selected international flights will hand out 100,000 copies of a poetry anthology along with the peanuts" (Meredith, 2000). Volkswagen put 40,000 copies of poetry books in the glove boxes of its new cars. Lancome paid for 15,000 copies of an anthology called 'Great Love Poems" given out on Valentine's Day (Meredith, 2000). In 2000, Monster.com announced record-breaking traffic spikes following the launch of its new advertising campaign during the broadcast of Super Bowl XXXIV. In the commercial, a young woman standing at an urban crossroads is 'advised' by a cast of characters as they walk past her. The advice is recited in the form of lines from Robert Frost's poem, The Road Not Taken. The final lines, delivered by an elementary school teacher and some of her students, suggest that the choices you make will make all the difference in your career.

In the abstract to his article: What Business can learn from the Poetry of Thomas Kinsella, John Fanning (2007) wrote: "A growing number of voices, [...], call for a greater embrace of literature and the arts in seeking to understand and master the world of marketing and business. The contention is that creative writers, such as novelists and poets, can articulate usefully the consumer condition. In this spirit, a close reading of the poetry of Thomas Kinsella, [...], can shed insight into a number of aspects of marketing and management practice. These aspects include the role of creative and innovative processes in business; the frequent misuse of scientific approaches; a tendency to settle for the second rate'the ease of the spurious'; the need for thoroughness in new product development - 'reading the ground'; and the consequences of corporate, and brand, amnesia."

Since marketing is only as good as the research that underpins it, could poetry have a role to play in consumer research? John F. Sherry, Jr. and John W. Schouten considered that poetry could be included in the various methods for data collection since it might serve to tap into consumers inner worlds, cogently arguing the case in A Role for Poetry in Consumer Research (Sherry and Schouten, 2002). They conclude: "We have discussed two ways that poetry can inform studies of consumer behavior: as reflexivity within research and a revelation of researcher point of view and as standalone qualitative research in its own right. Yet these are not the only means by which poetry may contribute to the discourse on consumer behavior. We have written this article simply to launch the tide of exploration" (Sherry and Schouten, 2002). 


\section{Poetry and Decision-making}

Can reading poetry make you think differently? Intuitively one would answer yes but is there empirical evidence to support this intuition? And will the process of understanding poems open spaces in your mind that will facilitate strategic planning, creativity, communications? For Clare Morgan "Reading poetry requires demands - a very particular way of thinking. And that way of thinking is vitally important in addressing the complexities of the economic, social, and political world we live in" (Morgan, 2010). Ted Buswick suggests "Reading poetry opens up new thinking spaces, and accessing those spaces requires you to develop a new set of thinking skills." (Buswick, Morgan, and Lange, 2005). Wolfgang Iser in his essay The Reading Process: A Phenomenological Approach, proposes that reading literary texts fosters an ability to ask questions and make connections. In the world of business "We look forward, we look back, we decide, we change our decisions, we form expectations, we are shocked by their non-fulfilment, we question, we use, we accept, we reject" (Iser, 1972). This is exactly what we do when we read a poem and try to grasp its meaning. Because of this Iser believes that literature gives us the chance to formulate the unformulated.

In What Poetry Brings to Business, Morgan talks about the notion of sharpeners and levellers. The Leveller likes to categorise, levels differences and emphasises similarities and finds the unique, unclassified sensation difficult. In contrast the Sharpener tolerates anomalies; is ready to think and perform symbolically, may seek out ambiguity and variability of classification; plans ideationally and is ready to assume an attitude toward 'the merely possible' (Morgan, 2010). Morgan's argues that engaging with poetry fosters a different mindset from that which typical analytical business training promotes. In today's complex world, leaders need to be sharpeners - the sharpener mindset is essential for strategic thinking and for being creative and innovative. Reuven Tsur ${ }^{1}$ undertook experiments to see whether how someone is trained to think makes a difference as to whether they use sharpener or leveller strategies and whether having been trained to work with poems enables someone to use different thinking strategies than if they were not. Tsur worked with groups of literary professionals and students as well as control groups of non-literary trained participants. Participants had to

1 Reuven Tsur is professor emeritus of Hebrew literature and literary theory at Tel Aviv University. He is known for his theory of Cognitive Poetics. evaluate different versions of a poetry text considering criteria such as static-dynamic, open-closed, emotionalunemotional. The differences perceived by the literary trained group were markedly greater. These results indicated that the non-literary participants tended to level out the differences and lacked the skills associated with those who had benefited from literary training.

\section{Poetry and Creativity}

Companies need to be innovative in order to differentiate. Can poetry help with creativity and innovation? A useful poem to study in the context of creativity is The Thought $F o x^{2}$ by Ted Hughes, which shows how the moment of creative insight creeps up on you. In Poetry in the Making Ted Hughes recommends: "Imagine what you are writing about. See it and live it. Do not think it up laboriously, as if you were working out mental arithmetic. Just look at $i t$, touch it, smell it, listen to it, turn yourself into it. When you do this, the words look after themselves, like magic" (Hughes, 2008).

Luc de Brabandere ${ }^{3}$ a BCG fellow and author of The Forgotten Half of Change argues that creativity is central to change in an organisation but suggests that central to creativity is the ability to shift perceptions since such changes can make way for imaginative leaps that generate new ideas that fuel organisational changes. He uses poetry to exemplify some of the challenges of creativity. One of his clients was a global hotel chain who put their request for proposals in the form of a poem in order to find consultants who would bring breadth and freshness to the project.

\section{Poetry and Organisational Learning}

Grisoni and Kirk (2006) in their paper. 'Voice, Verse and Va va voom: Illuminating Management

processes through Poetry' explored the power of using poetry as a process of critical reflection and organisational analysis in the management process. In this qualitative study, poems were created from the experiences of two members of the organisation in dialogue in relation to their roles and focus on specific decision-making critical incidents within the life of the organisation. Writing in the form of poetry enabled them to find a voice, increased personal learning, and new insights in relation to roles, management processes of decision-making and interpersonal dynamics in the organisation. Grisoni and

2 From The Hawk in the Rain (1957).

3 Luc de Brabandere is a senior advisor to BCG. He specializes in creativity, scenario building, and strategic vision techniques applied to business. 
Kirk's found that "the power of poetry lies in its ability to focus not only on events but also on behavioral and affective elements embedded in the episode. Poetry has been used to reveal hidden aspects of organizational life where the essence of an event or episode opens up an opportunity for greater understanding as well as the potential for change in individuals and organizations." Louise Grisoni (2007) argues that poetry "can be used to create a fusion between tangible, rational and explicit knowledge and tacit or implicit knowledge, providing opportunities to access new organizational knowledge and understandings and learning." Her paper is a case study of 60 middle and senior U.K.-based public services managers from one local authority who worked together to explore how research into their experiences might help address some problematic issues facing public services as well as developing ideas about best practice. Poetry in the form of haiku was used as a creative research method to access tacit knowledge, which, when combined with explicit knowledge and understanding, led to new insights and organisational learning.

\section{Final Words}

Just as: "The poet isn't trying to tell you something. The poet isn't trying to tell you anything. The poet is taking you on a journey of exploration, and where you arrive in the end, and the nature of the journey, will be different for each person" (Morgan, 2010) so this paper was a journey - an exploration - seeking to open your mind to the possibilities; to encourage you to see poetry in a different light. "If you're going to be able to think innovatively or creatively, you have to abandon the quest for swiftness of conclusion. You have to see thinking as an exploration, not just a means to an end" (Buswick, Morgan, and Lange, 2005). It has explored just a few of the potential benefits that studying poetry might bring to the world of business - a world where companies need to constantly find a blue ocean to operate in by differentiating themselves from other players, developing new markets and innovative products. Has the time now come to take poetry down from the shelf, dust it off and take a serious look at what it can do for the business world and then move on to harness that power?

\section{References}

Buswick, T., Morgan, C., Lange, K. (2005). Poetry in the boardroom: thinking beyond the facts: A roundtable discussion among Ted Buswick, Clare Morgan and Kirsten Lange. Journal of Business Strategy, 26 (1): 34-40.
Fanning, J (2007). What Business can Learn from the Poetry of Thomas Kinsella. Irish Marketing Review, 19 (1\&2): 46.

Grisoni, L., Kirk, P. (2006). Verse, voice and va va voom!: illuminating management processes through poetry. Management Decision, 44 (4): 512-525.

Grisoni, L. (2007). Cooking up a storm: Flavouring organisational learning with poetry. Organizational Learning and Knowledge Capabilities Conference, April. London, Canada.

Hughes, T. (2008). Poetry in the making: A handbook for writing and teaching. Faber \& Faber.

Iser, W. (1972). The reading process:

A phenomenological approach. New literary history, 3 (2): 279-299.

Klepper, M., Piller, I. (2000). The language of poetry and advertising - an interdisciplinary teaching project at Hamburg University. EESE - Erfurt Electronic Studies in English 5.

Lennox, W. J. (2005). Romance and reality. Originally Published: March 1, 2006. [available at: http:// www.poetryfoundation.org/poetrymagazine/ article/146660].

Meredith, R. (2000). The Media Business: Advertising; Marketing departments are turning to poets to help inspire their companies' clientele, New York Times, March 21, 2000.

Morgan, C. (2010). What poetry brings to business. University of Michigan Press.

Rubin, H. (2007). C.E.O. Libraries Reveal Keys to Success, New York Times, July 21, 2007.

Sherry Jr, J. F., Schouten, J. W. (2002). A role for poetry in consumer research. Journal of Consumer Research, 29 (2): 218-234.

Author

Gillian Pritchett, MA. CPFA. Teacher of various MBA programmes including International Business Strategy on the CEMS-MIM Programme at the University of Economics, Prague Founder of The Business Launchpad Consultant pritchett.g@gmail.com 